\title{
Produksi Rumput Gajah (Pennisetum purpureum) Dengan Pemberian Pupuk Organik Cair Fermentasi Limbah Rumen Sapi
}

\author{
Amin Pugut Prayogo, Nevy Diana Hanafi* dan Hamdan \\ Program Studi Peternakan, Fakultas Pertanian, Universitas Sumatera Utara \\ *Corresponding Author : Nevydiana@yahoo.co.id
}

\section{ABSTRACT}

Utilization of cattle rumen waste as liquid organic fertilizer is expected in planting, especially forage feed because the content of waste organic fertilizer rumen cattle fermentation has a fairly good nutrient content. This research was conducted at Bandar Klipah Market 10, Tembung Subdistrict, Deli Serdang Regency in August - November 2017 using Completely Randomized Design (CRD) with 4 treatment of 5 replications. The treatment were dosage of fermented rumen liquid (ml/plot) of P0: control, P1: $50 \mathrm{ml} / \mathrm{plot}$, P2: $100 \mathrm{ml} / \mathrm{plot}$, and P3: $150 \mathrm{ml} / \mathrm{plot}$. Variabels were observed plant height, number of tillers, fresh production, dry matter, and $N$ uptake. The results showed that fertilizer dosage treatment had significant effect $(P<0.05)$ on height and fresh production, but had no significant effect $(P>0.05)$ on dry matter production, number of tillers and $N$ uptake of napier grass (Pennisetum purpureum). The treatment of P3 with $150 \mathrm{ml}$ of fertilizer dosage showed heigher the plant height $(124.40 \mathrm{~cm})$, fresh production $(86.54 \mathrm{~g} / \mathrm{plot})$, dry matter production (32.46g / polybag), number of tillers (5.87), and $N$ uptake (1,99 g / plot) than other treatments. Production tends to increase along with the increase of dosage of waste cattle fermentation organic fertilizer. It was concluded that the fertilizer waste of cattle rumen fermentation can increase the production on napier grass (Pennisetum purpureum).

Keywords: Napier grass (Pennisetum purpureum), rumen cow fluid, productivity

\begin{abstract}
ABSTRAK
Pemanfaatan limbah rumen sapi sebagai pupuk organik cair diharapkan dapat membantu masyarakat dalam bercocok tanam khususnya hijauan pakan ternak. Kandungan pupuk organik cair fermentasi rumen sapi memiliki kandungan organik yang cukup baik. Penelitian ini dilakukan di desa Bandar Klipah pasar 10, Kecamatan Tembung, Kabupaten Deli Serdang pada bulan Juni November 2017. Penelitian ini menggunakan Rancangan Acak Lengkap (RAL) dengan 4 perlakuan 5 ulangan. Perlakuan menggunakan pupuk organik cair fermentasi rumen sapi $(\mathrm{ml} / \mathrm{plot})$ yang terdiri dari P0 : kontrol (tanpa pupuk cair), P1 : $50 \mathrm{ml} / \mathrm{plot}, \mathrm{P} 2: 100 \mathrm{ml} / \mathrm{plot}$, dan P3 : $150 \mathrm{ml} / \mathrm{plot}$. Peubah yang diamati yaitu tinggi tanaman, jumlah anakan, produksi segar, bahan kering, dan Serapan N. Hasil penelitian menunjukkan bahwa pemberian perlakuan dosis pemupukan berpengaruh nyata $(\mathrm{P}<0.05)$ terhadap tinggi dan produksi segar, dan tidak berpengaruh nyata $(\mathrm{P}>0.05)$ terhadap produksi bahan kering, jumlah anakan dan serapan $\mathrm{N}$ tanaman rumput gajah (Pennisetum purpureum). Perlakuan P3 dengan dosis pupuk $150 \mathrm{ml}$ dapat meningkatkan produksi tinggi tanaman $(124.40 \mathrm{~cm})$, produksi segar $(86.54 \mathrm{~g} /$ polybag $)$, produksi kering $(32.46 \mathrm{~g} / \mathrm{plot})$, jumlah anakan (5.87), dan serapan N (1,99 g/plot) dibanding perlakuan lainnya. Produksi cenderung meningkat seiring peningkatan dosis pupuk organik cair fermentasi rumen sapi. Disimpulkan bahwa pemberian pupuk organik cair fermentasi rumen sapi dapat meningkatkan produksi pada rumput gajah (Pennisetum purpureum).
\end{abstract}

Kata kunci : Rumput gajah (Pennisetum purpureum), cairan rumen sapi, produktifitas 


\section{PENDAHULUAN}

Rumen sapi sisa hasil rumah potong hewan merupakan salah satu limbah yang mikroorganismenya dapat dimanfaatkanuntuk pembuatan pupuk organik. Mikroorganisme dalam limbah rumen ini ternyata dapat dimanfaatkan sebagai starter/bioactivator yang dapat membantu mempercepat proses pengomposan bahan organik.

Fermentasi adalah salah satu usaha pengolahan yang digunakan untuk meningkatkan umur simpan produk dan diversifikasi olahannya. Fermentasi mempunyai arti yang berbeda bagi para ahli biokimia dan mikrobiologi industri. Arti fermentasi pada bidang biokimia dihubungkan dengan pembangkitan energi oleh katabolisme senyawa organik. Pada bidang mikrobiologi industri, menggambarkan setiap proses untuk menghasilkan produk dari pembiakan mikroorganisme (Suprihatin, 2010).

Pupuk organik cair adalah larutan mudah larut berisi satu atau lebih pembawa unsur yang dibutuhkan tanaman.Kelebihan dari pupuk organik cair adalah dapat memberikan hara sesuai dengan kebutuhan tanaman.

Penggunaan pupuk organik cair dapat membantu mengatasi kendala produksi pertanian. Pupuk organik cair selain dapat memperbaiki sifat fisik, kimia, dan biologi tanah, membantu meningkatkan produksi tanaman, meningkatkan kualitas produk tanaman, mengurangi penggunaan pupuk anorganik dan sebagai alternatif pengganti pupuk kandang (Hadisuwito, 2007).

Bedasarkan hasil paparan diatas maka perlu dilakukan suatu penelitian terhadap pemakaian cairan rumen ternak sapi dan dampaknya terhadap produktivitas (produksi segar, tinggi tanaman, jumlah anakan, produksi bahan kering dan serapan $\mathrm{N}$ ) pada Rumput Gajah (Pennisetum purpureum). Diharapkan hasil fermentasi rumen dari sapi dapat digunakan sebagai pupuk organik cair untuk dapat meningkatkan produktivitas rumput gajah (pennisetum purpureum).

\section{BAHAN DAN METODE}

Penelitian ini dilaksanakan di Desa Bandar Klipah Pasar 10 Kecamatan Tembung Kabupaten Deli Serdang dimulai dari Bulan Juni sampai dengan November 2017. Bahan yang digunakan adalah Rumen sapi sebagai bahan pupuk organik cair, air sebagai pelarut, molasses sebagai sumber ntrisi mikroorganisme dalam pembuatan pupuk organik cair, rumput gajah (Pennisetum purpureum). Sementara itu alat yang digunakan adalah cangkul untuk mengolah tanah, meteran untuk menukur tinggi tanaman, gembor untuk menyiram rumput setiap pagi dan sore, kertas label untuk penamaan polybag berdasarkan perlakuan, pisau dan polybag, timbangan sebagai alat menimbang bahan segar, alat untuk pengukur serapan $\mathrm{N}$ dan kamera untuk dokumentasi.

Penelitian ini menggunakan rancangan acak lengkap (RAL) yang diulang sebanyak 5 kali dengan 4 perlakuan. Perlakuan dosis pemupukan $(\mathrm{P})$ yang terdiri atas 4 taraf yaitu $0 \mathrm{ml}$ (P0), $50 \mathrm{ml}(\mathrm{P} 1), 100 \mathrm{ml}(\mathrm{P} 2), 150 \mathrm{ml}$ (P3). Dimana P0: tanpa pupuk organik cair fermentasi cairan rumen sapi sebagai control; P1: $50 \mathrm{ml}$ pupuk organik cair fermentasi cairan rumen sapi/polybag tanaman; P2: 100 $\mathrm{ml}$ pupuk organik cair fermentasi cairan rumen sapi/ polybag tanaman; P3: $150 \mathrm{ml}$ pupuk organik cair fermentasi cairan rumen sapi/ polybag tanaman

Total keseluruhan adalah : 4 × $5=20$ polybag, dimana tiap polybag terdapat 1 tanaman rumput gajah. 
Pelaksanaan Penelitian

Pembuatan Pupuk Organik Cair (POC) Limbah Rumen Sapi

\begin{tabular}{|c|}
\hline Rumen $5 \mathrm{~kg}+$ Air $3000 \mathrm{ml}$ \\
\hline$\downarrow$ \\
\hline Di homogenkan \\
\hline$\downarrow$ \\
\hline $\begin{array}{c}\text { Tambahkan molasses } \\
5000 \text { ml }\end{array}$ \\
\hline $\begin{array}{c}\text { Ditutup rapat ember dengan } \\
\text { menggunakan tali rafia } \\
\text { hingga tidak ada udara }\end{array}$ \\
$\downarrow$ \\
$\downarrow$ \\
\hline $\begin{array}{c}\text { Didiamkan selama 12 jam } \\
\downarrow\end{array}$ \\
\hline $\begin{array}{c}\text { Dilakukan pengamatan } \\
\text { setelah 12 jam, yaitu } \\
\text { organoleptik } \\
\text { (warna, bau dan tekstur) } \\
\text { dan mengukur pH. }\end{array}$ \\
\hline
\end{tabular}

Gambar 1. Bagan pembuatan pupuk organic cair limbah rumen sapi

\section{Pelaksanaan Penelitian}

Pengolahan tanah yaitu membalik dan menggemburkan struktur tanah agar menjadi gembur, sehingga memudahkan perakaran untuk masuk ke dalam tanah dan memudahkan akar tanaman menyerap unsur hara. Hal ini dilakukan agar tanaman terhindar dari gulma atau pun serangan hama lainnya.

Diisi polybag dengan tanah yang sudah ditentukan dengan ukuran $10 \mathrm{~kg}$ sebanyak 20 buah dan setiap polybag berisi 1 tanaman.Kemudian bibit berupa stek yang diambil setiap 2 ruas dan ditanam pada semua polybag sesuai dengan kode perlakuan ulangan.
Pemupukan dilakukan setiap sebulan sekali setelah panen.Diberikan kepada masing-masing polybag sesuai dengan perlakuan. Dosis pemberian pupuk yang diberikan.Yaitu sebanyak $50 \mathrm{ml}, 100 \mathrm{ml}$, dan $150 \mathrm{ml}$.

Kegiatan pemeliharaan meliputi kegiatan penyiraman yang dilakukan setiap pagi dan sore hari kecuali pada saat hujan tidak dilakukan. Penyulaman merupakan kegiatan yang dilakukan untuk mengganti tanaman yang mati atau pertumbuhannya kurang baik dalam 2 minggu setelah penanaman. Kegiatan lain yang perlu dilakukan adalah penyiangan, pendangiran yang dilakukan secara bersama-sama, yaitu pembersihan tanaman dari gulma dan penggemburan tanah kembali dengan berhatihati agar tidak merusak sistem perakaran tanaman dan pemupukan.

Pada penelitian ini trimming dilakukan pada saat tanaman berumur 21 hari, yang dimaksudkan untuk menyeragamkan tinggi tanaman. Tinggi pemotongan $15 \mathrm{~cm}$ dari permukaan tanah.

Pada penelitian ini pemanenan dilakukan sebanyak 3 kali dengan interval pemotongan 30 hari, dilakukan dengan memotong tanaman dengan menyisahkan 15 cm panjang tanaman dari permukaan tanah. Selama penelitian diamati perkembangan tanamannya seperti tinggi tanaman diukur setiap 1 minggu sekali dan jumlah anakan setiap 4 minggu sekali. Pada waktu pemotongan dilihat hasil produksi segarnya. Hal ini dilakukan untuk melihat hasil produksi dari efek pemberian POC fermentasi rumen sapi yang diberikan. Kemudian dilanjutkan pengamatan pada data yang dianalisis untuk mengetahui serapan $\mathrm{N}$ pada Rumput Gajah (Pennisetum purpureum).

\section{Analisis Data}

Pengambilan data pertumbuhan dilakukan secara bersamaan dengan waktu pemanenan yaitu 4 minggu sekali setiap perlakuan. Data yang perlu diambil yaitu data pertumbuhan tinggi tanaman dan jumlah anakan rumput gajah. Produksi segar rumput gajah dan setelah pemotongan dilakukan 
penimbangan. Kandungan serapan N dilakukan dengan analisis labu kedjhal.

Parameter yang diamati dalam penelitian ini antara lain produksi segar yaitu hasil dari hijauan setelah pemanenan. Produksi segar diperoleh dengan melakukan penimbangan daun rumput gajah dalam keadaan segar atau tanpa dilakukan pengeringan pada hasil pemotongan yang dilakukan setiap perlakuan, penimbangan produksi segar rumput gajah dilakukan setiap 30 hari sekali.

Produksi bahan kering diperoleh dari produksi bahan segar rumput gajah setelah dilakukan penimbangan. Selanjutnya di oven pada suhu $60^{\circ} \mathrm{C}$ selama $24 \mathrm{jam}$, kemudian ditimbang berat kering rumput tersebut. Selanjutnya diambil sampel untuk mengetahui berat kering tanaman pada oven $105^{\circ} \mathrm{C}$. Kemudian dilakukan konverse antara BK suhu $60^{\circ} \mathrm{C}$ dengan $\mathrm{BK}$ suhu $105^{\circ} \mathrm{C}$ untuk mengetahui persentase bahan kering. Untuk menentukan persentase bahan kering dapat digunakan rumus :

\section{$\mathrm{BK}=\underline{\text { Berat setelah pengeringan } \mathrm{X} 100 \%}$ Berat segar}

Tinggi tanaman yaitu jarak dari dasar tanaman di permukaan tanah ke atas daun atau bagian tertinggi dari tanaman dewasa, diukur dalam sentimeter. Dengan cara menegakkan seluruh daun keatas sampai tegak lurus, kemudian dilakukan pengukuran secara vertikal pada bagian tanaman yang paling tinggi dari permukaan tanah. Tinggi tanaman di ukur setiap 4 minggu sekali.

Jumlah anakan yaitu banyaknya anakan muda yang tumbuh dari 1 tanaman (biji, stek dan sebagainya). Anakan rumput gajah yang dihitung adalah anakan yang muncul dari dalam tanah atau tumbuh pada rhizome batang. Pada tanaman yang mempunyai anakan jika telah mempunyai daun, artinya daun telah membuka dengan sempurna. Jumlah anakan diukur setiap 4 minggu sekali.

Serapan N yaitu jumlah hara yang masuk ke dalam jaringan tanaman. Analisis kadar nitrogen dilakukan dengan metode kjehdahl. Serapan Nitrogen diukur dari batang utama dan tulang daun / ujung daun. Serapan $\mathrm{N}$ dilakukan sebanyak 3 kali pada saat pemanenan pertama, kedua dan ketiga. Proses pengukuran $\mathrm{N}$ adalah dimulai dari pengambilan sampel data yaitu ujung daun, penyiapan sampel, kemudian menganalisis dengan metode kjehdahl. Serapan N dihitung setiap pemanenan dengan menggunakan sampel daun yang telah dihaluskan menjadi tepung kemdian di analisis menggunakan tabung labu kjehdahl. Hasil perhitungan serapan $\mathrm{N}$ dapat menggunakan rumus :

Serapan $\mathrm{N}=\mathrm{PK}$ setelah oven $60^{\circ} \mathrm{C} \times \mathrm{N}-$ total labu kjehdahl

Dimana :

PK : Produksi Kering

\section{HASIL DAN PEMBAHASAN}

Hasil dari pengaruh pemberian pupuk organik cair fermentasi cairan rumen sapi terhadap produktivitas rumput gajah (Pennisetum purpureum) selama penelitian dapat dilihat pada Tabel 1 berikut :

Tabel 1. Rekapitulasi hasil penelitian

\begin{tabular}{lcccc}
\hline \multirow{2}{*}{ Parameter } & \multicolumn{4}{c}{ Perlakuan } \\
\cline { 2 - 5 } & $\mathrm{P} 0$ & $\mathrm{P} 1$ & $\mathrm{P} 2$ & $\mathrm{P} 3$ \\
\hline Tinggi Tanaman & $87.00^{\mathrm{d}}$ & $103.40^{\mathrm{c}}$ & $111.80^{\mathrm{b}}$ & $124.40^{\mathrm{a}}$ \\
Produksi Segar & $43.87^{\mathrm{b}}$ & $56.87^{\mathrm{b}}$ & $82.67^{\mathrm{a}}$ & $86.53^{\mathrm{a}}$ \\
Produksi Kering & $28.96^{\mathrm{a}}$ & $30.33^{\mathrm{a}}$ & $31.07^{\mathrm{a}}$ & $32.46^{\mathrm{a}}$ \\
Jumlah Ananakan & $3.53^{\mathrm{a}}$ & $4.80^{\mathrm{a}}$ & $5.20^{\mathrm{a}}$ & $5.87^{\mathrm{a}}$ \\
Serapan N & $1.81^{\mathrm{a}}$ & $1.92^{\mathrm{a}}$ & $1.96^{\mathrm{a}}$ & $1.99^{\mathrm{a}}$ \\
\hline Keterangan : & pemberian notasi yang berbeda & pada \\
& setiap parameter sejajar kearah baris \\
& menunjukan perlakuan memberikan \\
pengaruh yang berbeda nyata
\end{tabular}

\section{Tinggi Tanaman Rumput Gajah (Pennistum purpureum)}

Hasil penelitian diperoleh bahwa pemberian pupuk organik cair fermentasi rumen sapi dengan dosis yang berbeda memberikan pengaruh yang nyata terhadap pertumbuhan tinggi tanaman. Perbedaannya dapat dilihat pada table 1 . Pada pengujian lebih lanjut dengan menggunakan uji Duncan dapat diketahui bahwa rataan tinggi tanaman tertinggi terdapat pada perlakuan P3 yaitu $124.40 \mathrm{~cm}$ dan rataan tinggi tanaman terendah 
terdapat pada perlakuan P0 yaitu 87.00. Hasil ini lebih rendah dari penelitian Hidayat dan suwarno (2009), dimana data tinggi tanaman rumput gajah yang diberi perlakuan berupa pupuk kombinasi organik-urea yaitu P0 (236.67), P1 (245.55), P2 (254.35)

Rumput Gajah (Pennisetum purpureum) dapat tumbuh secara maksimal dari faktor lingkungan yang lembab serta keadaan tanah yang memiliki unsur hara yang lebih. Sehingga pertumbuhan tinggi tanaman Rumput Gajah (pennisetum purpureum) dapat dilihat secara nyata. Hal ini sesuai dengan pernyataan Kusuma (2014) yang menyatakan bahwa produksi Rumput Gajah (Pennisetum purpureum) akan menjadi baik apabila ditanam pada lahan yang baik dan mengandung nutrisi/hara yang cukup tersedia secara terus menerus. Pernyataan Van Soest (1982) bahwa cairan yang terdapat dalam rumen sapi banyak mengandung bahan organik.

Seiring peningkatan penggunaan dosis pupuk organik cair fermentasi rumen sapi terjadi peningkatan tinggi tanaman Rumput Gajah (Pennisetum purpureum). Peningkatan rataan tinggi tanaman dapat dilihat pada gambar berikut:

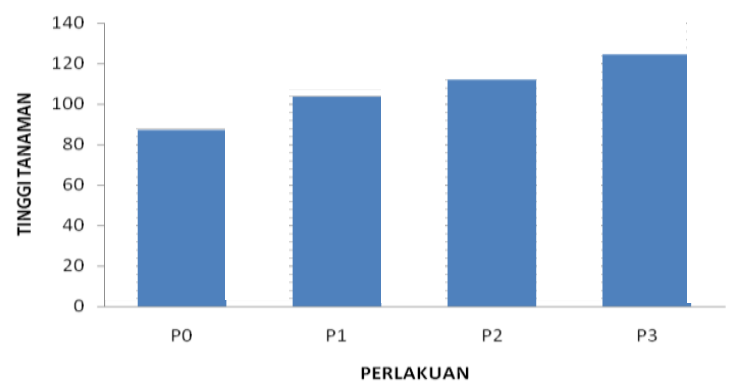

Gambar 2. Diagram batang tinggi tanaman

$\begin{array}{ccc}\text { Gambar } 2 \text { menunjukkan } & \text { terjadi } \\ \text { peningkatan tinggi tanaman } & \text { seiring } \\ \text { peningkatan penggunaan dosis } & \text { pupuk. }\end{array}$ Perbedaan tinggi tanaman Rumput Gajah (Pennisetum purpureum) disebabkan karena dosis pemberian pupuk pada perlakuan P3 lebih tinggi dibanding pada perlakuan yang tidak diberi pupuk (P0) atau sedikit diberi pupuk (P1 dan P2). Sehingga tanaman rumput gajah yang diberikan pupuk perlakuan P3 akan mendapatkan unsur hara yang lebih baik. Islami dan Utomo (1995) menyatakan bahwa pemupukan dilakukan untuk menyediakan unsur hara yang dibutuhkan oleh tanaman dalam setiap periode tumbuhnya.

\section{Produksi Segar Rumput Gajah (Pennistum purpureum)}

Hasil penelitian yang diperoleh menunjukkan bahwa dosis pupuk organik cair fermentasi rumen sapi berpengaruh nyata terhadap produksi segar tanaman Rumput Gajah (Pennisetum purpureum). Perbedaan yang nyata dapat dilihat pada Tabel 1 diatas.

Dimana rataan tertinggi dan berbeda nyata adalah perlakuan $\mathrm{P} 3=86.54 \mathrm{~g}$ dan rataan yang terendah pada perlakuan $\mathrm{P} 0=43,87 \mathrm{~g}$. $\mathrm{Hal}$ ini dikarenakan unsur $\mathrm{N}$ dalam pupuk cair masih sedikit. Sehingga rumput gajah kurang dalam menyerap unsur hara. Apabila tanaman kurang dalam menyerap unsur $\mathrm{N}$ maka tanaman akan menjadi kerdil. Dari hasil analisis pupuk cair organik fermentasi rumen sapi di Pusat Penelitian Kelapa Sawit (2017) menyatakan bahwa kandungan unsur $\mathrm{N}$ di pupuk cair lebih sedikit dibandingkan dengan unsur karbon. Nilai yang diperoleh dari $\mathrm{N}$ yaitu $0,22 \%$, sementara itu nilai dari karbon yaitu $4,08 \%$.

Seiring peningkatan penggunaan dosis pupuk organik cair fermentasi rumen sapi terjadi peningkatan produksi segar rumput gajah. Peningkatan produksi segar dapat dilihat dari gambar berikut :

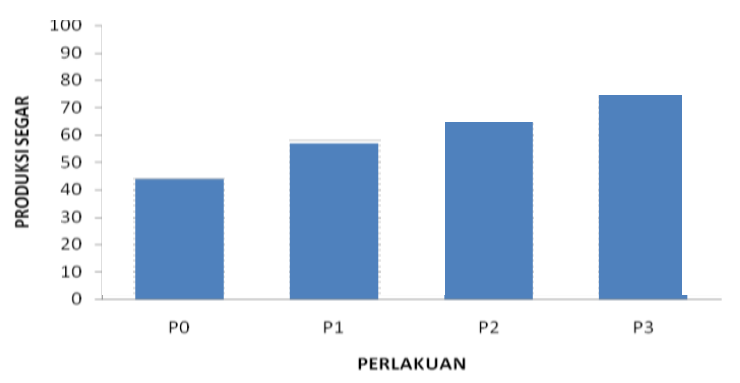

Gambar 3. Diagram batang produksi segar

Berdasarkan gambar 3 diatas dapat dilihat seiring peningkatan penggunaan dosis pupuk organik cair fermentasi rumen sapi terjadi peningkatan produksi segar rumput gajah. Dimana adanya perbedaan yang nyata pada masing-masing perlakuan dosis pupuk. Hal ini dikarenakan unsur hara dalam pupuk 
cair fermentasi rumen sapi belum terpenuhi secara maksimal. Kandungan Nitrogen dalam pupuk cair masih sedikit. Sehingga pertumbuhan rumput gajah menjadi terganggu.

\section{Produksi Bahan Kering Rumput Gajah (Pennisetum purpureum)}

Hasil penelitian diperoleh bahwa dosis pemberian pupuk organik cair fermentasi rumen sapi tidak berpengaruh nyata terhadap produksi bahan kering rumput gajah (Pennisetum purpureum). Hasil uji dengan menggunakan Duncan menyatakan pemberian dosis yang berbeda tidak menunjukkan perbedaan yang nyata pada setiap perlakuan. Hasil rataan produksi kering rumput gajah (Pennisetum purpureum) dapat dilihat pada Tabel 1.

Hasil statistik menunjukkan bahwa kecenderungan produksi bahan kering tertinggi didapat pada perlakuan P3 yaitu 32.46 gr dan data yang terendah pada perlakuan P0 yaitu 28.96 gr. Hal ini diduga pemberian pupuk yang belum mencukupi kebutuhan unsur hara sehingga menghasilkan produksi bahan kering yang lebih rendah. Hal ini tidak berbanding lurus dengan produksi segar. Dikarenakan faktor iklim yang dimana pada saat penelitian curah hujan tinggi, sehingga cahaya matahari tidak muncul secara maksimal dan mengganggu proses fotosintesis dari rumput gajah tersebut. Hal ini sesuai dengan pernyataan Budiana (1993) menyatakan bahwa makin tinggi laju proses fotosintesis maka makin tinggi karbohidrat dan protein yang dihasilkan tanaman sehingga bahan kering juga makin tinggi.

Seiring peningkatan penggunaan dosis pupuk organik cair fermentasi rumen sapi terjadi peningkatan produksi kering rumput gajah. Peningkatan produksi kering dapat dilihat pada gambar berikut :

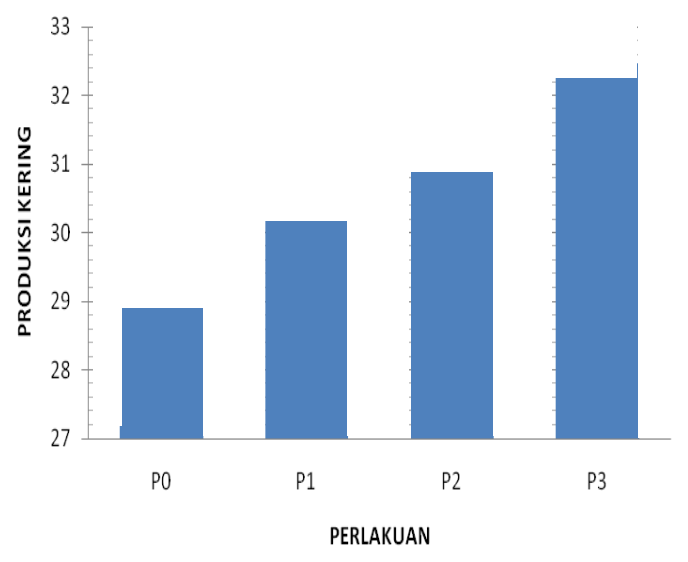

Gambar 4. Diagram batang produksi kering

Berdasarkan Gambar 4 diatas menunjukan produksi bahan kering rumput gajah (Pennisetum purpureum) tidak menunjukkan perbedaan yang signifikan. Pada perlakuan P1 dan P2 memiliki hasil produksi yang sama. Sedangkan pada $\mathrm{P} 3$ hasil produksi tidak jauh dengan perlakuan P2 dan P1. Hal ini dikarenakan faktor kandungan zat Nitrogen yang terdapat dalam pupuk cair organik fermentasi rumen sapi yang sangat sedikit. Sehingga laju produksi bahan kering dari rumput gajah sangat kecil. Hal ini sesuai dengan pernyataan Muhakka et al (2012) yang menyatakan bahwa pupuk yang memiliki kandung Nitrogen yang banyak, dapat melakukan proses pembentukan protein tanaman sehingga meningkatkan pertumbuhan vegetative tanaman, seperti batang, daun, dan akar.

\section{Jumlah anakan Rumput Gajah (Pennisetum purpureum)}

Hasil penelitian menunjukkan pemberian dosis yang berbeda tidak memberikan pengaruh yang nyata terhadap jumlah anakan rumput gajah (Pennisetum purpureum). Hasil rataan jumlah anakan dapat dilihat pada Tabel 1. Kecenderungan jumlah anakan rumput gajah (Pennisetum purpureum) yang tertinggi terdapat pada $\mathrm{P} 3$ yaitu dengan 5.87 tunas/rumpun dan rataan terendah pada P0 yaitu 3.53 tunas/rumpun tanaman rumput gajah (Pennisetum purpureum). 
Kekurangan unsur $\mathrm{N}$ juga sebagai penyebab jumlah anakan yang dihasilkan oleh rumput gajah tidak maksimal. Kandungan $\mathrm{N}$ dalam pupuk organik cair fermentasi rumen sapi sangat sedikit. Sehingga tanaman sulit dalam berkembang dengan baik. Karena unsur $\mathrm{N}$ sangat mendukung untuk pertumbuhan vegetatif pada tanaman rumput gajah (Pennisetum purpureum). Iklim juga mempengaruhi pertumbuhan tunas dan akan terjadi fotosintesis. Hal ini sesuai dengan pernyataan Poerwidodo (1992) dan Sutejo (2002) menyatakan bahwa nitrogen sangat diperlukan untuk merangsang pertumbuhan vegetatif, memperbesar ukuran daun dan meningkatkan kandungan klorofil tanaman. Harjadi (1979) menyatakan bahwa hasil dari proses fotosintetsis akan ditranslokasikan ke bagian lain dari tanaman yang akan digunakan untuk pertumbuhan vegetatif dan reproduktif.

Seiring peningkatan penggunaan dosis pupuk organik cair fermentasi rumen sapi terjadi adanya peningkatan jumlah anakan rumput gajah. Peningkatan jumlah anakan dapat dilihat gambar berikut :

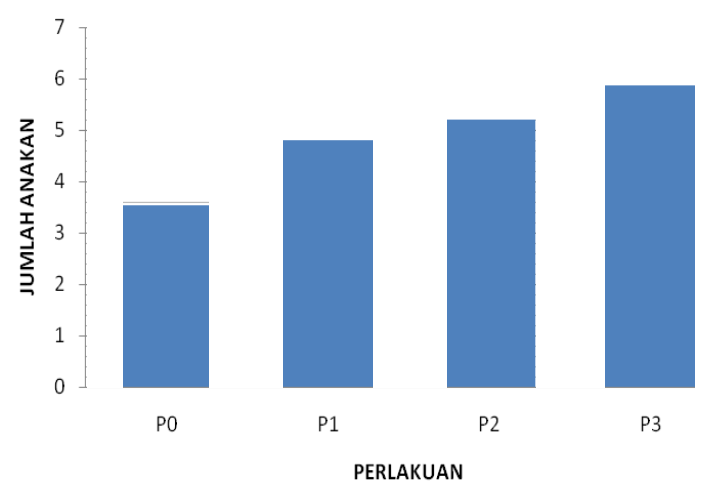

Gambar 5. Diagram batang jumlah anakan

Berdasarkan gambar 5 diatas dapat diketahui bahwa rata-rata jumlah anakan P3 cenderung memiliki nilai yang lebih besar dibandingkan perlakuan lainnya. Karena perlakuan tanpa pemberian pupuk berakibat pada kurang tersediannya unsur hara yang dibutuhkan oleh tanaman rumput gajah sehingga pertumbuhannya menjadi tidak maksimal. Hal ini sesuai dengan pernyataan Kusuma (2014) menyatakan bahwa pertumbuhan tanaman rumput gajah terendah didapat pada perlakuan kontrol (P0) atau tanpa pemberian pupuk baik dilihat dari rata-rata tinggi tanaman, jumlah anakan maupun jumlah daun. Pemberian pupuk terhadap tanaman rumput gajah mempunyai jumlah anakan dan jumlah daun lebih banyak dibandingkan dengan kontrol.

\section{Serapan N Rumput Gajah (Pennisetum purpureum)}

Hasil penelitian tidak menunjukkan adanya pengaruh yang nyata terhadap serapan $\mathrm{N}$ rumput gajah (Pennisetum purpureum). Hasil rataan serapan $\mathrm{N}$ rumput gajah dapat dilihat pada Tabel 1. Hasil penelitian didapatkan Data yang tertinggi didapat pada P3 yaitu $1.99 \mathrm{~g}$, dan yang paling rendah pada P0 yaitu 1.81 gr. Ini lebih rendah dari hasil Mariana (2016) yang nilai rataan P0, P1, P2, dan P3 berturut-turut adalah 97.85, 132.23, 134.08, dan 197.97 dengan penggunaan pupuk cair urin sapi terhadap rumput gajah (Pennisetum purpureum). Hal ini disebabkan berbedanya nilai $\mathrm{N}$ antara pupuk cair rumen sapi dengan pupuk cair urin sapi. Hasil analisis yang dilakukan terhadap pupuk cair rumen sapi diketahui kandungan $\mathrm{N}$ pada pupuk cair fermentasi rumen sapi sangat rendah dapat di lihat pada tabel 2 berikut :

Tabel 2. Hasil analisis pupuk organik cair fermentasi rumen sapi

\begin{tabular}{lcc}
\hline \multicolumn{1}{c}{ Parameter } & Satuan & Hasil Uji \\
\hline Nitrogen & $\%$ & 0,22 \\
C. Organik & $\%$ & 4,08 \\
C/N & - & 18,55 \\
\hline
\end{tabular}

Sumber : laboratorium pusat penelitian kelapa sawit (2016)

Tinggi serapan $\mathrm{N}$ sejalan dengan produksi bahan kering. Hal ini dikarenakan serapan $\mathrm{N}$ memiliki korelasi terhadap produksi bahan kering. Pada uji Duncan dihasilkan bahwasanya antara serapan $\mathrm{N}$ dan produksi bahan kering sama-sama tidak menunjukkan perbedaan yang nyata $(\mathrm{P}>0,05)$. Faktor yang mempengaruhi ketidakstabilan tanaman rumput gajah dalam memproduksi serapan $\mathrm{N}$ yaitu media tanam/tanah. Tanah yang digunakan pada saat penelitian yaitu tanah yang memilki unsur hara yang sedikit. Tanah ini juga memiliki $\mathrm{pH}$ berkisar 4 hingga 
4,5. Jadi tanaman yang ditanam pada tanah yang memiliki $\mathrm{pH}$ tersebut, maka tanaman akan sulit dalam berkembang. Hal ini sesuai dengan pernyataan Rinsema (1983) yang menyatakan bahwa persyaratan $\mathrm{pH}$ tanah yang dikendaki oleh tanaman sangat bervariasi, kebanyakan tanaman tumbuh kurang baik pada $\mathrm{pH}$ kurang dari 5.

\section{SIMPULAN}

Hasil penelitian memperlihatkan bahwasannya penggunaan pupuk organik cair (POC) fermentasi cairan rumen sapi berpengaruh terhadap tinggi tanaman, produksi segar, produksi bahan kering, jumlah anakan dan serapan $\mathrm{N}$ rumput gajah (Pennisetum purpureum) pada dosis POC fermentasi cairan rumen sapi $150 \mathrm{ml} /$ polybag.

\section{REFERENSI}

Agus, F. 2005. Analisis Kimia Tanah, Tanaman, Air, dan Pupuk. Balai Penelitian Tanah. Departemen Pertanian.

Budiana. 1993. Produksi Tanaman Hijauan Pakan Ternak Tropik. Fakultas Peternakan, Universitas Gajah Mada, Yogyakarta.

Hadisuwito, S. 2007. Membuat Pupuk Kompos Cair. Agro Media. Jakarta Selatan.

Harjadi, M. M. S. S. 1979. Pengantar Agronomi. PT. Gramedia, Jakarta.

Hidayat Nur and Suwarno, 2009.Studi Produksi dan Kualitas Rumput Gajah (Pennisetum purpureum) Varietas Thailand yang di Pupuk dengan Kombinasi Organik-Urea.pdf. Fakultas Peternakan Universitas jendral Soedirnan, Purwokerto.Diakses pada tanggal 6 September 2017.

Islami T, Utomo WH. 1995. Hubungan

Tanah Air dan Tanaman. Semarang.

IKIP Semarang Press.
Kusuma, M.E. 2014. Respon Rumput Gajah (Pennisetum purpureum) Terhadap Pemberian Pupuk Majemuk. Fakultas Peternakan Universitas Kristen Palangka Raya.

Mariana, R. 2016. Respon Pemberian Pupuk Cair Urin Sapi Fermentasi MOL Buah Terhadap Peningkatan Produktivitas dan Serapan $N$ Rumput Gajah (Pennisetum pupureum). Skripsi Sarjana. Program Studi Peternakan Fakultas Pertanian.Universitas Sumatera Utara. Medan.

Muhakka, Napoleon. A, Rosa. P. 2012. Pengaruh Pemberian Pupuk Cair Terhadap Produksi Rumput Gajah Taiwan (Pennisetum purpureum schumach). pdf. Diakses pada tanggal 13 Juni 2017.

Poerwowidodo. 1992. Telaah Kesuburan Tanah. Penerbit Angkasa, Bandung.

Pusat Penelitian Kelapa Sawit. 2017. Hasil Analisis Pupuk Organik Cair Fermentasi Rumen Sapi.Medan Sumatera Utara.

Rinsema, W. T. 1983. Pupuk dan Cara Pemupukan. Bhatara Karya Aksara. Jakarta.

Suprihatin. 2010. Teknologi Fermentasi. UNESA University Press. Surabaya.

Sutejo, M.M. 2002. Pupuk dan Cara Pemupukan. Penerbit Rineka Cipta, Jakarta.

Van Soest, P.J. 1982. Nutritional Ecology Of The Ruminant. 0 \& $\mathrm{B}$ Books, inc. Corvallis. Oregon. Page 374 
